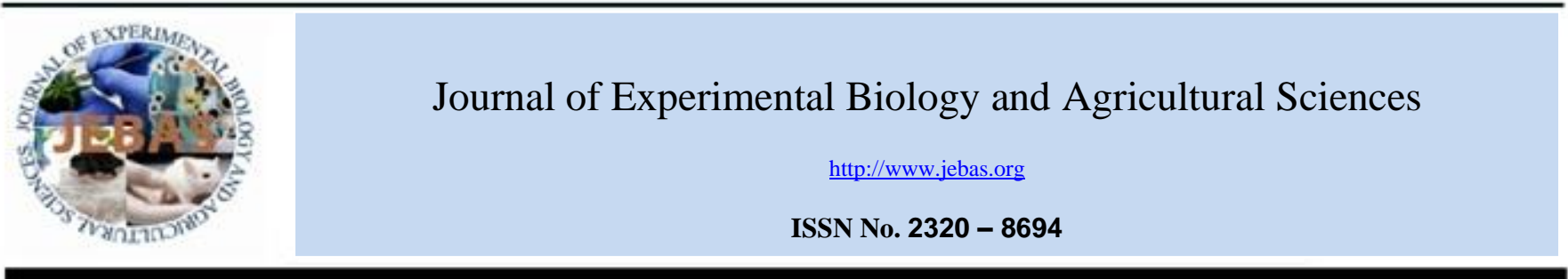

\title{
EFFECTIVENESS OF SOLAR THERMOELECTRIC COOLER FOR FISH PRESERVATION: EXPERIMENTAL STUDY ON QUALITY CHARACTERISTICS OF Pangasius bocourti FISH FILLETS DURING STORAGE
}

\author{
Olipriya Biswas ${ }^{1,2}$, Palani Kandasamy ${ }^{1, *}$, Goutam Mandal $^{3}$, Debasis Panda ${ }^{4}$
}

${ }^{1}$ Department of Agricultural Engineering, Institute of Agriculture, Visva-Bharati (A Central University), Sriniketan-731236, West Bengal, India
${ }^{2}$ Department of Fishery Engineering, Faculty of Fishery Sciences, West Bengal University of Animal \& Fishery Sciences, Kolkata-700094, India
${ }^{3}$ Department of Horticulture and Post Harvest Technology, Institute of Agriculture, Visva-Bharati (A Central University), Sriniketan-731236, West Bengal, India
${ }^{4}$ Department of Crop Physiology, Institute of Agriculture, Visva-Bharati (A Central University), Sriniketan-731236, West Bengal, India

Received - July 04, 2021; Revision - September 16, 2021; Accepted - October 18, 2021

Available Online - October 30, 2021

DOI: http://dx.doi.org/10.18006/2021.9(5).618.629

\section{KEYWORDS \\ Basa fish fillets \\ Solar thermoelectric cooler \\ Cooling capacity \\ Coefficient of performance \\ Quality parameters \\ Sensory attributes}

\begin{abstract}
Preservation of fish products is a big issue where inconsistent electricity supply. In the current study, a solar thermoelectric cooler (STC) was fabricated by exploiting the solar energy and its cooling potential for fish preservation was evaluated. The STC consists of a photovoltaic (PV) panel, battery, PV charge controller, thermoelectric cooling system, and cooler box. The temperature of the STC decreased to $7.4^{\circ} \mathrm{C}$ within 90 minutes and then reached $5 \pm 0.2^{\circ} \mathrm{C}$ in $150 \mathrm{~min}$. The cooling capacity and coefficient of performance of the STC were $23.8 \mathrm{~W}$ and 0.44 , respectively, at an input electric current of $3.5 \mathrm{~A}$. The Pangasius bocourti fish fillets were stored in the STC for 10 days and tested its quality at 2 days intervals. On day 10, thiobarbituric acid, peroxide, $\mathrm{pH}$, water binding ability, total plate count values were $1.65 \mathrm{mg} \mathrm{MDA} / \mathrm{kg}, 5.04 \mathrm{mEqO}_{2} / \mathrm{kg}, 7.16,26.18 \%$, and $4.26 \log \mathrm{CFU} / \mathrm{g}$, respectively. A significant reduction in hardness, springiness, and chewiness values was observed, whereas no cohesiveness changes. The color values $\mathrm{L}^{*}$ and $\mathrm{a}^{*}$ decreased significantly, whereas $\mathrm{b}^{*}$ and $\Delta \mathrm{E}$ increased. The sensory attributes were found in the range of 5.2-6.0 on the $10^{\text {th }}$ day. As the quality parameters showing an acceptable level, STC could be an alternate green option for fish preservation.
\end{abstract}

* Corresponding author

E-mail: pkandasamy1973@gmail.com (Palani Kandasamy)

Peer review under responsibility of Journal of Experimental Biology and Agricultural Sciences.

Production and Hosting by Horizon Publisher India [HPI] (http://www.horizonpublisherindia.in/).

All rights reserved.
All the articles published by Journal of Experimental Biology and Agricultural Sciences are licensed under a Creative Commons Attribution-NonCommercial 4.0 International License Based on a work at www.jebas.org.

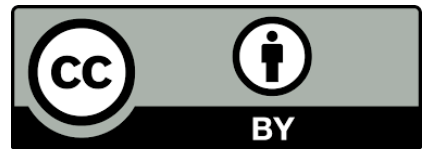




\section{Introduction}

Fish is a rich resource of protein, omega-3 fatty acids, vitamins, and minerals and plays a significant role in human nutrition. Supplementation of fish, a minimum of two times a week in the human diet, is recommended and considered to be healthy (Khalili Tilami \& Sampels, 2018). Among farmed fish species, basa (Pangasius bocourti) is one of the most consumed fish worldwide due to its excellent taste, color, deliciousness, great acceptability, affordable price, and commercial appearance in the form of fillet without skin or thorns (Guimarães et al., 2016). Pangasius primarily existed in fresh and brackish waters across the south and southeast Asian countries. Despite the above, such fishes are highly perishable due to microbial attack, lipid oxidation, and enzymatic activities leading to the deterioration of their quality (Nielsen \& Jessen, 2007).

As fish spoilage is temperature-dependent, storing at a low temperature is the best option. Refrigeration can slow down the chemical and microbiological activities and associated deterioration during storage (Secci \& Parisi, 2016). The studies have been reported that the fish stored at a chilled temperature ranging from 0 to $5^{\circ} \mathrm{C}$, has a storage life of 7-16 days, this depending on the species (Mohan et al., 2008; Viji et al., 2015; Remya et al., 2018). The shelf life of fish can also be increased up to 3 months during frozen storage at $-20^{\circ} \mathrm{C}$ (Nielsen \& Jessen, 2007; Sriket \& La-ongnual, 2018). However, preservation of perishable foods by cooling is generally a big issue where there is an inconsistent electricity supply. Moreover, in the tropical climate, maintaining the quality of perishable foods such as meat, fish, drink, and milk is a great challenge (Dai et al., 2003).

Solar energy, an abundant supply of natural energy resources, has a great potential to encounter the growing energy demand. The solar radiation is directly converted into electrical energy through photovoltaic (PV) cells. In the solar cooling system, solar energy is converted into electrical energy by the PV system and used for running refrigerators. Solar cooling emerges to be an attractive proposition as the cooling demand increased (Dai et al., 2003). The thermoelectric device is used as a cooler by converting electrical energy into a temperature difference. This system has many advantages, including compact size, portable, reliable, low production cost, less maintenance, no harm to the environment, and possible outdoor use combined with solar-PV cells (Chen et al., 2014).

The thermoelectric cooling system is working on the principles of the Peltier effect, briefly, when an electric current is made to flow in a closed circuit made of two dissimilar metals, thermal energy is evolved at one metal junction and discharged at the other junction depending on the direction of the current flow (Guo et al., 2020; Aboelmaaref et al., 2020). The thermoelectric cooling system has many advantages; in fact, it does not require liquid refrigerants, consumes less electric power, is easy to develop as portable and lightweight devices for outdoor use, is highly suitable in small and temporary places, no irreversible harm to the environment, noiseless, compact in size, lightweight, portable, high reliability, low-cost production, less maintenance, long lifetime, viable for outdoor use combined with solar photovoltaic cells, and attractive to use as mini-refrigerator for preserving foods and drugs in small places (Chen et al., 2014; Mirmanto et al., 2019; Aboelmaaref et al., 2020).

Various studies have been reported on the cooling performance of the solar thermoelectric refrigerator. Dai et al. (2003) reported that the solar-powered thermoelectric refrigerator could maintain the temperature in the range of $5-10^{\circ} \mathrm{C}$ and has a coefficient of performance (COP) of 0.3 under test conditions. Abdul-Wahab et al. (2009) demonstrated that the refrigeration temperature decreased from $27^{\circ} \mathrm{C}$ to $5^{\circ} \mathrm{C}$ within $45 \mathrm{~min}$, and the COP of the device was about 0.16 . Chen et al. (2014) demonstrated that the thermoelectric chiller driven by solar cells was cooled water from $18.5^{\circ} \mathrm{C}$ to $13^{\circ} \mathrm{C}$. In contrast, COP of the device varied between 0.55 and 1.05 , while solar insolation altered between $450 \mathrm{~W} / \mathrm{m}^{2}$ and $1000 \mathrm{~W} / \mathrm{m}^{2}$. Ohara et al. (2015) designed a portable thermoelectric refrigerator for vaccine storage. The system achieved a minimum temperature of $3.4^{\circ} \mathrm{C}$ and diminished power consumption by $50 \%$ when it reached twice the temperature difference.

The retail fish sellers used ices to preserve fish, and the retailers in the rural and remote areas were not easy to obtain the ices. Moreover, these ices occasionally do not fulfill the food grades and become significant sources of contamination. The solar thermoelectric cooler could be helpful in those areas where inconsistent conventional electricity supply. Besides, research on the preservation of fish products in thermoelectric coolers is not found in the literature. It has mainly prompted the formulation of the present study. The objectives of this study were (i) to evaluate the cooling performance of the fabricated solar thermoelectric cooler (ii) to assess the chemical, texture, color, microbial load, and sensory attributes of basa fish fillets during storage.

\section{Materials and Methods}

\subsection{Sample preparation}

The study was conducted in the Department of Agricultural Engineering, Visva-Bharati University, Santiniketan, West Bengal, India in the hot climate conditions during March-May 2019. Freshly harvested live basa fish ( $P$. bocourti) were procured from a local fish farm at Bolpur and immediately brought to the Department of Agricultural Engineering, Visva-Bharati University, Santinietan, West Bengal. The fish were stunned by applying a 
blow on the skull with a hammer before decapitation. After stunning, the slaughtering and bleeding of the fish were carried out immediately by cutting the gill arches and main blood vessels from the heart with a sharp knife (Leary et al., 2016). Then manually filleted the fish, after being scaled, beheaded, and gutted. The fillets were packed in low-density polyethene pouches about $100 \mathrm{~g}$ per pouch, prepared 12 pockets, and sealed using a zip lock. The fillet pockets were stored in the solar thermoelectric cooler for 10 days. The samples were withdrawn from the cooler at a time interval of 2 days to evaluate changes in the quality in terms of texture, color, thiobarbituric acid, peroxide value, $\mathrm{pH}$, water binding ability, microbial load, and sensory attributes.

\subsection{Fabrication of the solar thermoelectric cooler}

The solar thermoelectric cooler (STC) consists of a cooler box, solarPV module, storage battery, energy control unit, thermoelectric module, heat sinks, and cooling fans. The cooler box is a rotomoulded plastic container made up of food-grade double tough highdensity polyethene (HDPE), each $6 \mathrm{~mm}$ thick, and a polyurethane insulation foam layer of $50 \mathrm{~mm}$ thick filled in the double tough wall construction. The internal dimension of the cooler box is $0.36 \mathrm{~m} \times$ $0.28 \mathrm{~m} \times 0.25 \mathrm{~m}$ with a volume of $0.0252 \mathrm{~m}^{3}$. A stretch holds down loops having a constant pressure mechanism used for closing the lid. Thermal conductivities of HDPE and polyurethane foam insulation materials are 0.44 and $0.028 \mathrm{~W} / \mathrm{mK}$, respectively. The insulation is used to inhibit the backflow of heat and prevent any loss in the cooler's performance affected by external heat. The estimated refrigeration of the STC was $41.52 \mathrm{~W}$ (Eq. 1). The cooler box was purchased from Aristoplast Products Pvt. Ltd, Mumbai, India.

A polycrystalline type solar-PV module (power rating: $100 \mathrm{~W}_{\mathrm{p}}$; efficiency: $13.2 \%$; size: $1032 \times 672 \mathrm{~mm}$ ) used in this study. The PV module's power rating is based on the power requirement of the STC (see Eq. 8). The electrical power generated by the PV module is utilized to drive the STC. The PV module was supplied by Vinova Energy Systems Private Limited, Tamil Nadu, India. The specifications of the PV module are presented in Table 1. A tubular type lead-acid battery (storage capacity: $80 \mathrm{Ah}$ ) is used to store the $\mathrm{PV}$ power and exploit the store electricity when there is no sunshine. Based on the thermoelectric cooler, the battery capacity was chosen. Silvex Exports Private Limited, Mumbai, India, supplied the storage battery. A solar charge controller regulates the supply of electric power from the PV module to the storage battery.

The thermoelectric cooling system consists of a thermoelectric module, heat sinks, and fans. The thermoelectric module (TEM) is a solid-state heat pump that builds hot and cold sides when electric current flows across the module. The specifications of the TEM are presented in Table 1. The TEM converts the direct solar current (DC) to alternate current (AC) power. Two heat sinks, one (size: $10 \times 10 \times 3 \mathrm{~cm}$ ) at the hot side and the other (size: $4 \times 4 \times 2.6 \mathrm{~cm}$ ) at the cold side of the TEM, were fixed. Besides, two low power consumption fans $(3 \mathrm{~W})$, one at the backside of the hot side heat sink and the other at the cold side heat sink, were fixed as shown in figure 1 . This complete thermoelectric assembly was fixed onto the cooler box wall, as shown in figure 2 . The heat sink at the hot side amplifies the heat transfer rate from the hot side of the TEM; thus, it will dispel the heat outside of the cooler box; it also protects TEM from overheating and maintains an ambient environment. The heat sink at the cold side of the TEM is used to cool the cooler cabinet. The cooling fans are used to reject extra heat from the hot side of the TEM to the ambient environment, better ventilation, and maintain the TEM's effectiveness. The schematic diagram of an experimental solar thermoelectric cooler is shown in figure 2 .

Table 1 Specifications of the solar PV module and thermoelectric module

\begin{tabular}{|cccc|}
\hline Solar PV module & & \multicolumn{2}{c|}{ Thermoelectric module } \\
\hline PV module type & VE12100 & TEM type & TEC1-12705S \\
\hline Maximum rated power $\left(\mathrm{W}_{\mathrm{p}}\right)$ & $100 \mathrm{~W}_{\mathrm{p}}$ & $\mathrm{I}_{\max }$ & $5.3 \mathrm{~A}$ \\
\hline Maximum power voltage $\left(\mathrm{V}_{\mathrm{mp}}\right)$ & $18.58 \mathrm{~V}$ & $\mathrm{U}_{\max }$ & $57 \mathrm{~W}$ \\
\hline Maximum power current $\left(\mathrm{I}_{\mathrm{mp}}\right)$ & $5.98 \mathrm{~A}$ & $\mathrm{Q}_{\max .}$ @ $\Delta \mathrm{T}=0$ & $67^{\circ} \mathrm{C}$ \\
\hline Open circuit voltage $\left(\mathrm{V}_{\mathrm{oc}}\right)$ & $22.58 \mathrm{~V}$ & $\Delta \mathrm{T}_{\max }$ & $40{ }^{\circ} \mathrm{C}$ \\
\hline Short circuit current $\left(\mathrm{I}_{\mathrm{sc}}\right)$ & $5.96 \mathrm{~A}$ & $\mathrm{~T}_{\mathrm{h}}$ & $127 \mathrm{couples}$ \\
\hline Module efficiency $\left(\eta_{\mathrm{m}}\right)$ & $13.2 \%$ & $\mathrm{~N}-\mathrm{P}$ junction & $138^{\circ} \mathrm{C}$ \\
\hline Output tolerance & $5 \%$ & Maximum temperature & $40 \times 40 \times 3.8 \mathrm{~mm}$ \\
\hline Maximum series fuse rating & $10 \mathrm{~A}$ & Dimension & $0.411 \mathrm{~W} / \mathrm{m}^{2} \mathrm{~K}$ \\
\hline Operating temperature & $-40 \mathrm{to} 85{ }^{\circ} \mathrm{C}$ & Thermal conductance $(\mathrm{K})$ & $0.1882 \mathrm{~V} / \mathrm{K}$ \\
\hline Module dimension & $1032 \times 672 \mathrm{~mm}$ & Seebeck coefficient $(\alpha)$ & $1.989 \Omega$ \\
\hline Weight & $8 \mathrm{~kg}$ & Electrical resistance $(\mathrm{R})$ & $29 \mathrm{~g}$ \\
\hline
\end{tabular}

PV module at standard test condition: solar irradiance $1.0 \mathrm{~kW} / \mathrm{m}^{2}$; module temperature $25^{\circ} \mathrm{C}$; wind speed $1.0 \mathrm{~m} / \mathrm{s}$. 


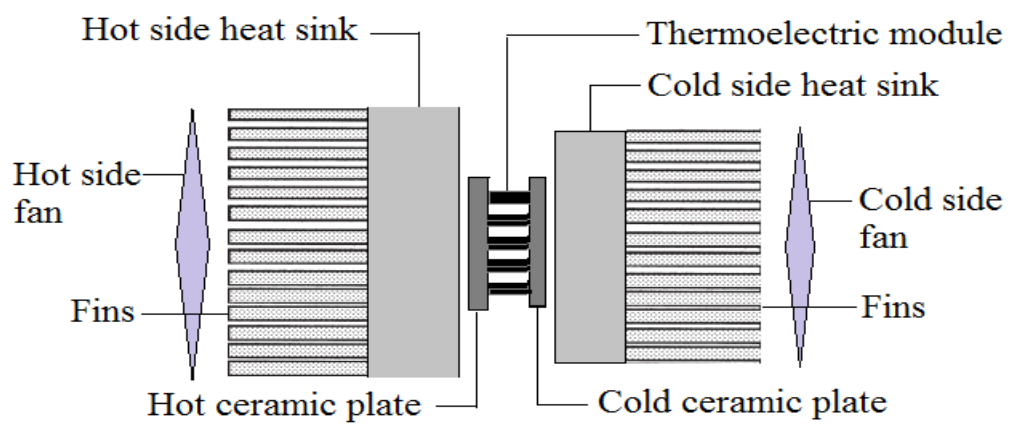

Figure 1 Schematic arrangement of components of thermoelectric cooling system

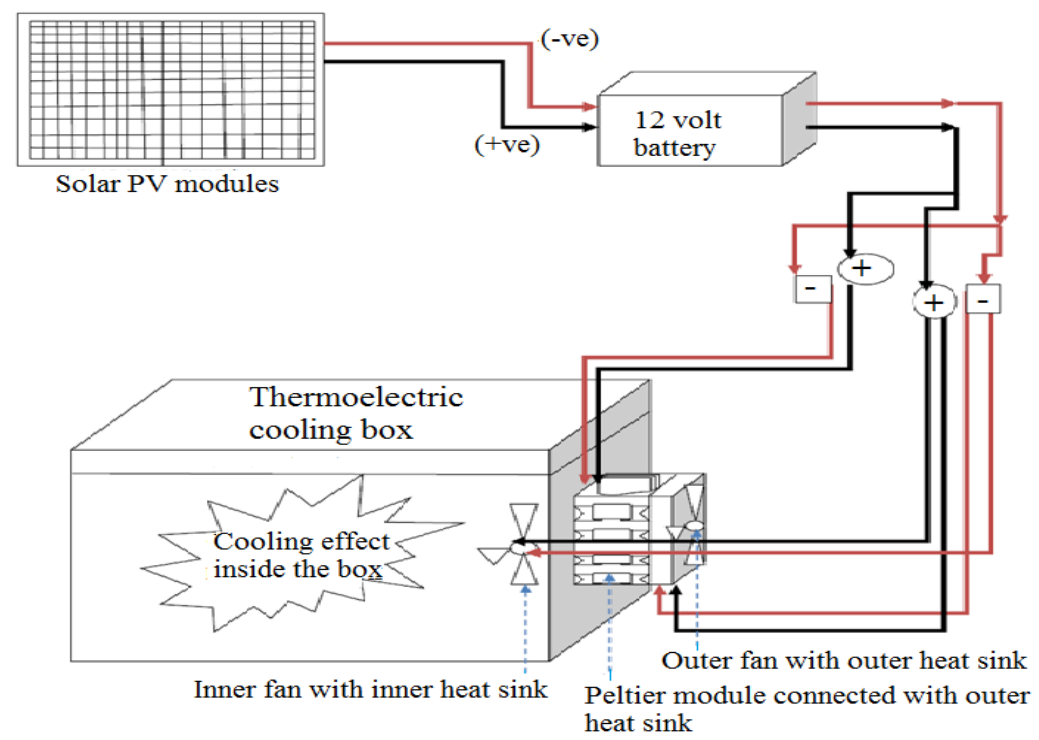

Figure 2 Schematic diagram of the experimental solar thermoelectric cooler

\subsection{Testing of STC}

The solar-PV panel is fixed with the required angle $\left(40^{\circ}\right)$ to receive maximum solar radiation incidence on the panel. It was connected with the battery terminals through a solar charge controller using respective cables. The positive side of the TEM turns the cold side due to absorption of heat, which transferred to the other side, which became the hot side. The cold side of the TEM was fixed inside of the cooler box, and the hot side fitted outside (Figure 2). The temperature of the cold and hot sides of the TEM was measured using T-type thermocouples, which connected to the cold and hot sides, other ends with the digital temperature indicator. The voltage and electric current was measured using a digital energy meter. The PV power was utilized to drive the STC in the daytime (from 8:00 to 17:00); after, battery power was exploited from 17:00 to $23: 30$.

\subsection{Estimation of heat gain of cooled space}

The TEM can pump the total heat gain of the cooled space (refrigeration load) of the STC. The total heat energy $\left(\mathrm{Q}_{\mathrm{T}}\right)$ is the sum of the heat flow entering the cooler box, conduction heat loss inside the TEM, product heat, and heat given off by the fan.

$$
\mathrm{Q}_{\mathrm{T}}=\mathrm{Q}_{\mathrm{w}}+\mathrm{Q}_{\mathrm{m}}+\mathrm{Q}_{\mathrm{p}}+\mathrm{Q}_{\mathrm{f}}
$$

The heat loss through the wall of the cooler box can be estimated using the following formula (Gökçek \& Şahin, 2017):

$$
\begin{gathered}
\mathrm{Q}_{\mathrm{w}}=\mathrm{A}_{\mathrm{c}} \mathrm{U}\left(\mathrm{T}_{0}-\mathrm{T}_{\mathrm{i}}\right) \\
\mathrm{U}=\frac{1}{\frac{1}{\mathrm{~h}_{\text {in }}}+\frac{\mathrm{X}_{\mathrm{p}}}{\mathrm{K}_{\mathrm{p}}}+\frac{\mathrm{X}_{\mathrm{i}}}{\mathrm{K}_{\mathrm{i}}}+\frac{1}{\mathrm{~h}_{\text {out }}}}
\end{gathered}
$$

The conduction heat loss inside the TEM can be estimated as (Abdul-Wahab et al., 2009; Bjørk et al., 2014): 


$$
Q_{m}=\frac{K_{m} A_{m}\left(T_{h}-T_{c}\right)}{X_{m}}
$$

The product heat refers to the heat given off by the stored product. In this study, $2.0 \mathrm{~kg}$ fish fillets were kept in the STC as product material at $5 \pm 0.2^{\circ} \mathrm{C}$. The specific heat capacity of the fish fillets is about $3.85 \mathrm{~kJ} / \mathrm{kg} \mathrm{K}$. The product heat in the cooler can be determined as the method described by Gökçek \& Şahin (2017):

$$
Q_{p}=\frac{M_{p} C_{p}\left(T_{p i}-T_{p f}\right)}{3.6 \Delta t}
$$

The heat given off by the fan on the cold side of the TEM was calculated using its rated electrical power consumption (AbdulWahab et al., 2009; Gökçek \& Şahin, 2017):

$$
\mathrm{Q}_{\mathrm{f}}=\mathrm{N}_{\mathrm{f}} \mathrm{F}_{\mathrm{r}}
$$

\subsection{Evaluation of cooling performance}

The cooling capacity of the TEM or amount of heat absorbed at the cold side of the TEM can be estimated as follows (Dai et al., 2003; Chen et al., 2014):

$$
\mathrm{Q}_{\mathrm{c}}=\alpha \mathrm{IT}_{\mathrm{C}}-0.5 \mathrm{I}^{2} \mathrm{R}-\mathrm{K} \Delta \mathrm{T}
$$

The electrical energy consumption of the TEM $\left(\mathrm{P}_{\mathrm{t}}\right)$ can be estimated as follows (Dai et al., 2003; Chen et al., 2014):

$$
\mathrm{P}_{\mathrm{t}}=\mathrm{I}^{2} \mathrm{R}+\alpha \mathrm{I} \Delta \mathrm{T}
$$

The total power consumption of the STC and its coefficient-ofperformance (COP) can be estimated as follows (Gökçek \& Şahin, 2017):

$$
\begin{aligned}
& P_{\text {stc }}=P_{t}+P_{f} \\
& C O P=\frac{Q_{c}}{P_{s t c}}
\end{aligned}
$$

The heat energy in the cooled space of the STC $\left(\mathrm{Q}_{\mathrm{T}}\right)$ is absorbed in the cold side of the TEM $\left(\mathrm{Q}_{c}\right)$ during the cooling process. Therefore, we can use either $\mathrm{Q}_{\mathrm{T}}$ or $\mathrm{Q}_{\mathrm{c}}$ to calculate the COP of a thermoelectric cooler (Gökçek \& Şahin, 2017; Aboelmaaref et al., 2020).

\subsection{Chemical analysis}

Fish fillets were minced using a mixer grinder for chemical analysis. Thiobarbituric acid (TBA) is a measure of oxidative stability of the fish muscle. A spectrophotometer (Model: LT2203, Labtrinics, India) was used to estimate the TBA at $538 \mathrm{~nm}$, expressed as mg of malonaldehyde per kg sample (Tarladgis et al., 1960). TBA value is a measure of oxidative stability of the fish muscle. The standard iodometric method (AOCS, 1992) was used to determine the peroxide content, expressed as milliequivalents oxygen per kg sample. The fish sample's $\mathrm{pH}$ value was estimated using a digital $\mathrm{pH}$ meter after homogenization in distilled water $(1: 5 \mathrm{w} / \mathrm{v})$. Gravimetrically, the water-binding ability of the fish sample was calculated by taking the weight difference of the initial and centrifuged sample, expressed in percent (Hassan et al., 2016).

\subsection{Texture profile analysis}

A texture analyzer (TA-HDi, Stable Micro Systems, U.K.) fitted with a cylindrical platen probe of $50 \mathrm{~mm}$ diameter was used to measure texture profile (Sun et al., 2018). The fish fillet samples size of $3.0 \times 2.0 \times 1.5 \mathrm{~cm}$ were placed on the heavy-duty platform fixture and compressed perpendicular to the muscle fibre posture using the probe at a test speed of $2 \mathrm{~mm} / \mathrm{s}$ through the two-cycle sequence, trigger force of $0.15 \mathrm{~N}$, and using $50 \mathrm{~kg}$ load cell. The texture profile parameters are computed as described by the manufacturer. Hardness was measured as resistance at a maximum compressive force of the first bite to deform the sample, expressed in Newton. Cohesiveness is the ratio of the second compression's positive force to the first compression, dimensionless. Springiness is measured as the distance recovered by the sample between the first and second compressions expressed in $\mathrm{mm}$. The chewiness was calculated by the multiplication of hardness $\times$ cohesiveness $\times$ springiness, expressed in Newton. Each experiment was replicated three times.

\subsection{Color analysis}

The color analysis was done using a Minolta colorimeter (Minolta Co. Ltd., Japan) under the hunter lab system. The color measurements of $\mathrm{L}^{*}$ (lightness), $\mathrm{a}^{*}$ (redness), and $\mathrm{b}^{*}$ (yellowness) were recorded at three different locations on the fish fillets surface and determined the mean value. The reference color values $\left(\mathrm{L}_{\mathrm{b}}{ }^{*}\right.$, $\left.\mathrm{a}_{\mathrm{b}}{ }^{*}, \mathrm{~b}_{\mathrm{b}}{ }^{*}\right)$ before storage and color values of stored samples $\left(\mathrm{L}_{\mathrm{s}}{ }^{*}, \mathrm{a}_{\mathrm{s}}{ }^{*}\right.$, $\mathrm{b}_{\mathrm{s}}{ }^{*}$ ) were used in the determination of change in color $(\Delta \mathrm{E})$, as defined by Kandasamy \& Mukherjee (2019):

$$
\Delta \mathrm{E}=\sqrt{\left(\mathrm{L}_{\mathrm{b}}^{*}-\mathrm{L}_{\mathrm{s}}^{*}\right)^{2}+\left(\mathrm{a}_{\mathrm{b}}^{*}-\mathrm{a}_{\mathrm{s}}^{*}\right)^{2}+\left(\mathrm{b}_{\mathrm{b}}^{*}-\mathrm{b}_{\mathrm{s}}^{*}\right)^{2}}
$$

\subsection{Microbial analysis}

Total plate count (TPC) was estimated using the plate count agar method (APHA, 1992). Ten grams of minced fish fillet sample was homogenized with $100 \mathrm{ml}$ standard saline solution to obtain a 1/10 dilution. One $\mathrm{mL}$ from this dilution was transferred into a test tube containing a $9 \mathrm{~mL}$ saline solution to get the subsequent dilution. One $\mathrm{mL}$ was transferred aseptically to sterile Petri-plates from each dilution, added $15 \mathrm{~mL}$ melted agar medium $\left(45^{\circ} \mathrm{C}\right)$, mixed, and solidified. The inoculated plates were incubated for five days at $7^{\circ} \mathrm{C}$ for total psychrotrophic counts. The colony counter was used to count the colonies, an average number of colonies was multiplied by the dilution factor to obtain complete counts as a colony-forming unit (CFU) per gram of sample. This count converted to the total plate count of $\log \mathrm{CFU} / \mathrm{g}$ of the sample. Triplicate measurements were done in each experiment. 


\subsection{Sensory evolution}

Sensory evaluation of fish fillets was carried out with slight modifications in the method given by Kulawik et al. (2016). The fish fillets were cooked with standard local culinary practice. At the evaluation time, the samples were warmed using a microwave oven for $1 \mathrm{~min}$, cut across the center to make equal size, and arranged treatment wise and then served warm to panel lists for sensory evaluation. The panel lists consist of 10 semi-trained male and female staff members and research scholars of the Institute. The panel members should have neither vegetarians nor allergic to fish and seafood. The members were requested not to consume meals, drinks, mints, etc., for at least one $\mathrm{h}$ before the session. Portable water was provided to rinse their mouth between the samples. The panel lists asked to evaluate the samples for flavor, juiciness, texture, taste, and overall acceptability according to their perception. An 8-point descriptive scale rating (where $8=$ like extremely and $1=$ dislike extremely) was used to evaluate the sensory attributes. On each sensory parameter, determined the average value and standard deviation.

\subsection{Statistical analysis}

Average values of each experiment with standard deviations reported. One-way analysis of variance used to analyze the data adopted a completely randomized design. To analyze the experimental data, we used SPSS software (SPSS Inc., Chicago, USA).

\section{Results}

\subsection{Performance of solar thermoelectric cooler}

The temperature variation of the TEM's cold and hot side with the loaded item is shown in Figure 3(a). The cold side temperature $\left(T_{c}\right)$ of TEM decreased to $7.4^{\circ} \mathrm{C}$ from $30^{\circ} \mathrm{C}$ within $90 \mathrm{~min}$, and then gradually reduced, reached to $5 \pm 0.2^{\circ} \mathrm{C}$ in $150 \mathrm{~min}$. The hot side temperature $\left(\mathrm{T}_{\mathrm{h}}\right)$ increased to $40.2^{\circ} \mathrm{C}$. The temperature difference $(\Delta \mathrm{T})$ depends on the hot and cold side's temperature, raised over the experimental time. Besides, the temperature of fish fillets dropped to $6.5^{\circ} \mathrm{C}$ from an initial temperature of $21.5^{\circ} \mathrm{C}$. It also absorbed that the temperatures continued till the end of the experiment. On the other hand, no significant change in outdoor temperature was observed.

The effect of electric current input on cooling capacity and COP of the STC are shown in Figure 3(b). The results showed that increasing electric current input results in decreasing the COP of the STC. The raising electric power consumption of the TEM while increasing the electric current input, and therefore reducing the COP of the STC (see Eq. 10). On the other hand, the cooling capacity increased while increasing the electric current input. The increased flow of electrons within the TEM decreases the cold side temperature, thus increasing the cooling capacity of the TEM. By increasing electric current intake from 0.9 A to $3.5 \mathrm{~A}$, cooling capacity increased from $12.9 \mathrm{~W}$ to $23.8 \mathrm{~W}$, but the COP decreased from 0.98 to 0.44 . The maximum cooling capacity of $23.8 \mathrm{~W}$ and the COP of 0.44 was observed at the electric current input of $3.5 \mathrm{~A}$.

The STC has driven continuously for a period of about 5-6 h after the sunset. The sunset times varied from 18:09 to 18:38 during the study period. The store electricity in the battery is exploited to drive the cooler during this time. A temperature change in the STC was noticed in this study while using the battery power and observed that the temperature at the cold side maintained about $5^{\circ} \mathrm{C}$ and gradually increased. The current flow rate also decreased gradually.
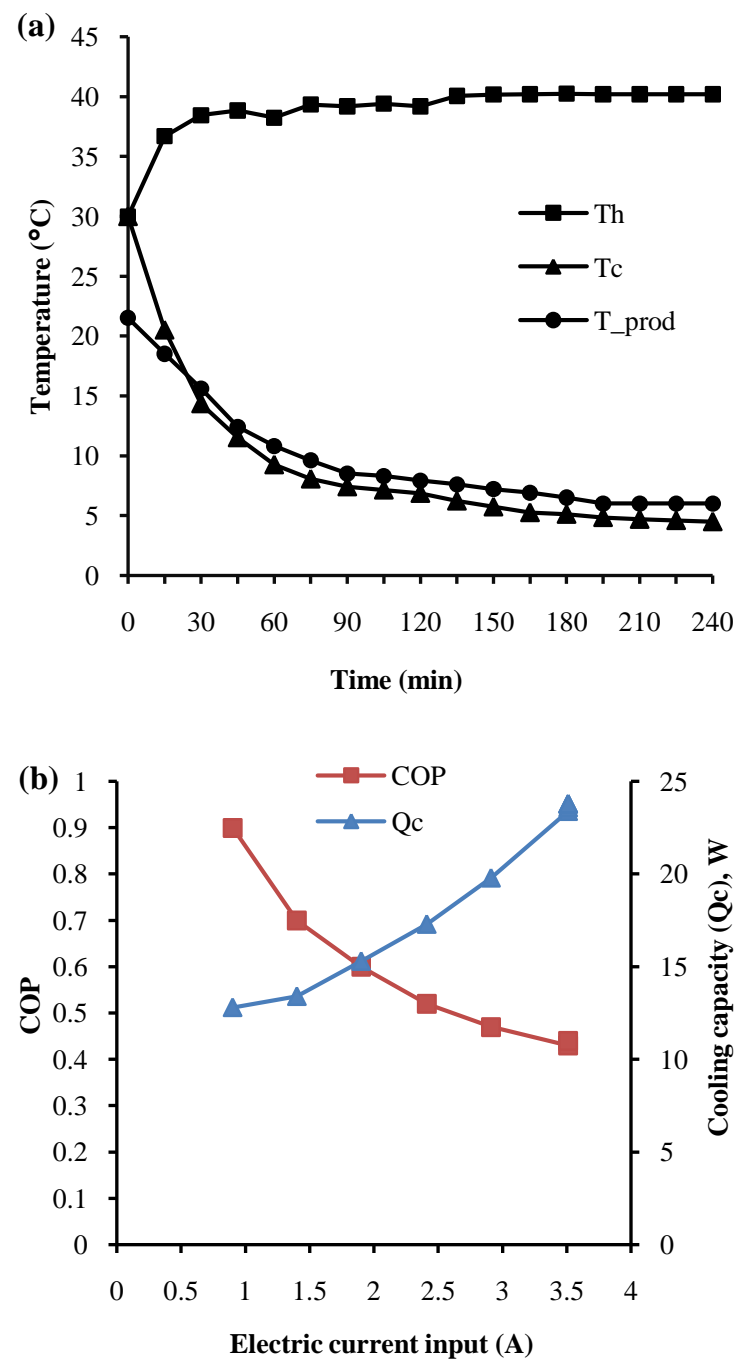

Figure 3 Performance of the solar thermoelectric cooler (a) temperature variations of product, hot and cold sides of the thermoelectric module (b) variations of COP and $Q_{c}$ against electric current input 


\subsection{Thiobarbituric acid value}

The changes in thiobarbituric acid (TBA) value of basa fish fillets during storage in the STC at $5 \pm 0.2^{\circ} \mathrm{C}$ are presented in Table 2. It is clear from the table that the TBA value increased gradually and reached $1.65 \mathrm{mg} \mathrm{MDA} / \mathrm{kg}$ sample on the 10th day from an initial value of $0.21 \mathrm{mg} \mathrm{MDA} / \mathrm{kg}$ sample. The increase in TBA value during storage may be due to the denaturation of the fish muscle cells that liberates the kind of catalysts that accelerate the lipid oxidation (Sriket \& La-ongnual, 2018). The limit of TBA value's acceptability is in the range of $1.0-2.0 \mathrm{mg} \mathrm{MDA} / \mathrm{kg}$ sample; an undesirable odor and taste will develop beyond this limit (Mohan et al., 2008; Viji et al., 2015). In the present study, the TBA value showed about $1.65 \mathrm{mg} \mathrm{MDA} / \mathrm{kg}$ sample on the 10th day, which is within the general range of $1.0-2.0 \mathrm{mg} \mathrm{MDA} / \mathrm{kg}$ sample.

\subsection{Peroxide value}

The changes in peroxide value of basa fish fillets during storage in STC at $5 \pm 0.2^{\circ} \mathrm{C}$ are reported in Table 2 . The peroxide value of fish fillets significantly increased from an initial value of 1.26 to 5.04 $\mathrm{mEqO}_{2} / \mathrm{kg}$ sample during 10 days storage period. In the current study, the peroxide value of fish fillets showed less than 5.5 $\mathrm{mEqO}_{2} / \mathrm{kg}$ fat in STC during the storage period of 10 days, and no off-flavor or odor was registered.

\section{$3.4 \mathrm{pH}$ value}

The $\mathrm{pH}$ value of the basa fish fillets increased significantly during the storage period of 10 days in STC at $5 \pm 0.2^{\circ} \mathrm{C}$ (Table 2). The initial $\mathrm{pH}$ value was found to be 6.56 , whereas, after 10 days, the value was 7.16 .

Table 2 Quality parameters of $P$. bocourti fish fillets during storage in the solar thermoelectric cooler at $5 \pm 0.2^{\circ} \mathrm{C}$ for 10 days

\begin{tabular}{|c|c|c|c|c|c|c|c|}
\hline \multirow{2}{*}{$\begin{array}{c}\text { Quality } \\
\text { categories }\end{array}$} & \multirow{2}{*}{ Parameters } & \multicolumn{6}{|c|}{ Days of storage } \\
\hline & & 0 & 2 & 4 & 6 & 8 & 10 \\
\hline \multirow[t]{4}{*}{$\begin{array}{c}\text { Biochemical } \\
\text { quality }\end{array}$} & TBA & $0.21 \pm 0.06^{\mathrm{a}}$ & $0.47 \pm 0.05^{\mathrm{a}}$ & $0.73 \pm 0.03^{\mathrm{a}}$ & $0.95 \pm 0.08^{\mathrm{a}}$ & $1.19 \pm 0.08^{\mathrm{a}}$ & $1.65 \pm 0.09^{\mathrm{a}}$ \\
\hline & Peroxide & $1.27 \pm 0.08^{\mathrm{b}}$ & $2.54 \pm 0.13^{\mathrm{b}}$ & $3.48 \pm 0.10^{\mathrm{b}}$ & $3.94 \pm 0.13^{\mathrm{b}}$ & $4.58 \pm 0.12^{\mathrm{b}}$ & $5.04 \pm 0.21^{b}$ \\
\hline & $\mathrm{pH}$ & $6.56 \pm 0.18^{\mathrm{c}}$ & $6.67 \pm 0.15^{\mathrm{c}}$ & $6.79 \pm 0.18^{c}$ & $6.92 \pm 0.25^{\mathrm{c}}$ & $7.08 \pm 0.24^{\mathrm{c}}$ & $7.16 \pm 0.24^{\mathrm{c}}$ \\
\hline & WBA & $15.02 \pm 0.11^{\mathrm{d}}$ & $18.16 \pm 0.18^{\mathrm{d}}$ & $20.53 \pm 0.30^{\mathrm{d}}$ & $22.75 \pm 0.16^{\mathrm{d}}$ & $24.38 \pm 0.13^{\mathrm{d}}$ & $26.18 \pm 0.21^{\mathrm{d}}$ \\
\hline \multirow[t]{4}{*}{ Texture profile } & Hardness $(\mathrm{N})$ & $28.71 \pm 0.23^{\mathrm{a}}$ & $26.72 \pm 0.51^{\mathrm{a}}$ & $25.53 \pm 0.39^{\mathrm{a}}$ & $24.29 \pm 0.51^{\mathrm{a}}$ & $22.59 \pm 0.53^{\mathrm{a}}$ & $20.36 \pm 0.55^{\mathrm{a}}$ \\
\hline & Cohesiveness & $0.27 \pm 0.03^{\mathrm{a}}$ & $0.28 \pm 0.09^{b}$ & $0.27 \pm 0.04^{\mathrm{c}}$ & $0.27 \pm 0.05^{\mathrm{d}}$ & $0.26 \pm 0.06^{\mathrm{e}}$ & $0.27 \pm 0.08^{f}$ \\
\hline & $\begin{array}{l}\text { Springiness } \\
(\mathrm{mm})\end{array}$ & $0.94 \pm 0.09^{\mathrm{c}}$ & $0.87 \pm 0.09^{\mathrm{c}}$ & $0.84 \pm 0.08^{\mathrm{c}}$ & $0.82 \pm 0.06^{\mathrm{c}}$ & $0.81 \pm 0.06^{\mathrm{c}}$ & $0.79 \pm 0.06^{\mathrm{c}}$ \\
\hline & $\begin{array}{l}\text { Chewiness } \\
(\mathrm{N})\end{array}$ & $7.31 \pm 0.87^{\mathrm{d}}$ & $6.34 \pm 1.40^{\mathrm{d}}$ & $5.99 \pm 1.64^{\mathrm{d}}$ & $5.45 \pm 1.55^{\mathrm{d}}$ & $4.76 \pm 0.72^{\mathrm{d}}$ & $4.45 \pm 1.72^{\mathrm{d}}$ \\
\hline \multirow[t]{4}{*}{ Color values } & $\mathrm{L}^{*}$ & $63.74 \pm 0.47^{\mathrm{a}}$ & $61.93 \pm 0.12^{\mathrm{a}}$ & $60.73 \pm 0.66^{\mathrm{a}}$ & $59.44 \pm 0.79^{\mathrm{a}}$ & $58.65 \pm 0.30^{\mathrm{a}}$ & $57.83 \pm 0.56^{\mathrm{a}}$ \\
\hline & $a^{*}$ & $4.86 \pm 0.23^{b}$ & $4.16 \pm 0.20^{\mathrm{b}}$ & $3.63 \pm 0.29^{b}$ & $3.50 \pm 0.35^{\mathrm{b}}$ & $3.19 \pm 0.25^{\mathrm{b}}$ & $3.07 \pm 0.19^{b}$ \\
\hline & $b^{*}$ & $15.27 \pm 0.20^{\mathrm{c}}$ & $16.17 \pm 0.11^{\mathrm{c}}$ & $17.07 \pm 0.24^{c}$ & $17.83 \pm 0.18^{\mathrm{c}}$ & $18.25 \pm 0.21^{\mathrm{c}}$ & $18.76 \pm 0.20^{c}$ \\
\hline & $\Delta \mathrm{E}$ & $0.0+0.0$ & $2.14 \pm 0.10^{\mathrm{d}}$ & $3.69 \pm 0.09^{\mathrm{d}}$ & $5.21 \pm 0.05^{\mathrm{d}}$ & $6.13 \pm 0.11^{\mathrm{d}}$ & $7.06 \pm 0.14^{\mathrm{d}}$ \\
\hline Microbial load & TPC & $2.13 \pm 0.07^{\mathrm{e}}$ & $2.61 \pm 0.16^{\mathrm{e}}$ & $3.12 \pm 0.25^{\mathrm{e}}$ & $3.38 \pm 0.11^{\mathrm{e}}$ & $3.85 \pm 0.23^{\mathrm{e}}$ & $4.26 \pm 0.14^{\mathrm{e}}$ \\
\hline \multirow[t]{5}{*}{$\begin{array}{c}\text { Sensory } \\
\text { attributes }\end{array}$} & Flavour & $6.96 \pm 0.11^{\mathrm{a}}$ & $6.66 \pm 0.03^{\mathrm{a}}$ & $6.54 \pm 0.11^{\mathrm{a}}$ & $6.38 \pm 0.18^{\mathrm{a}}$ & $6.15 \pm 0.08^{\mathrm{a}}$ & $5.94 \pm 0.14^{\mathrm{a}}$ \\
\hline & Juiciness & $6.53 \pm 0.13^{\mathrm{b}}$ & $6.46 \pm 0.07^{\mathrm{b}}$ & $6.18 \pm 0.16^{\mathrm{b}}$ & $6.05 \pm 0.14^{\mathrm{b}}$ & $5.74 \pm 0.12^{\mathrm{b}}$ & $5.20 \pm 0.08^{\mathrm{b}}$ \\
\hline & Texture & $6.63 \pm 0.07^{\mathrm{c}}$ & $6.51 \pm 0.17^{\mathrm{c}}$ & $6.37 \pm 0.13^{\mathrm{c}}$ & $6.13 \pm 0.15^{\mathrm{c}}$ & $5.63 \pm 0.15^{\mathrm{c}}$ & $5.32 \pm 0.20^{\mathrm{c}}$ \\
\hline & Taste & $6.86 \pm 0.04^{\mathrm{d}}$ & $6.71 \pm 0.09^{\mathrm{d}}$ & $6.53 \pm 0.22^{\mathrm{d}}$ & $6.37 \pm 0.12^{\mathrm{d}}$ & $6.21 \pm 0.13^{\mathrm{d}}$ & $5.98 \pm 0.16^{\mathrm{d}}$ \\
\hline & $\begin{array}{c}\text { Overall } \\
\text { acceptability }\end{array}$ & $6.61 \pm 0.09^{\mathrm{e}}$ & $6.53 \pm 0.13^{\mathrm{e}}$ & $6.22 \pm 0.12^{\mathrm{e}}$ & $6.08 \pm 0.18^{\mathrm{e}}$ & $5.84 \pm 0.21^{\mathrm{e}}$ & $5.61 \pm 0.13^{\mathrm{e}}$ \\
\hline
\end{tabular}

Data are presented as mean \pm standard deviation $(\mathrm{n}=3)$. Mean value with same superscript in each row showed significant variation at $1 \%$.

TBA = Thiobarbituric acid $(\mathrm{mg} \mathrm{MDA} / \mathrm{kg})$, Peroxide $\left(\mathrm{mEqO}_{2} / \mathrm{kg}\right), \mathrm{WBA}=$ Water binding ability $(\%), \mathrm{L}^{*}=$ Lightness, $\mathrm{a}^{*}=$ Redness, $\mathrm{b}^{*}=$ Yellowness, $\Delta \mathrm{E}=$ Change in colour, and TPC $=$ Total plate count $(\log \mathrm{CFU} / \mathrm{g})$. 


\subsection{Water binding ability}

In the present investigation, the water binding ability (WBA) increased significantly during the storage period. At the beginning of the experiment, the WBA of the fish fillets was $15.02 \%$, whereas it increased up to $26.18 \%$ on the 10 th day (Table 2).

\subsection{Texture profile analysis}

Changes in the texture profile of pangasius fish fillets during storage under STC at $5 \pm 0.2^{\circ} \mathrm{C}$ are presented in Table 2. A significant reduction in hardness value was observed throughout the storage period, which gradually reduced from an initial value of $28.71 \mathrm{~N}$ to $20.36 \mathrm{~N}$. The reduction in hardness may be due to the weakening of the muscle fibrils aggregation over the storage time. The cohesiveness value of 0.27 was recorded, which indicates the fish sample had a sufficient elasticity. It is an indication of the goodness of the internal bonding of muscle fibrils during storage. A decreasing trend in springiness was observed over the storage period. The springiness value decreased to $0.79 \mathrm{~N}$ from an initial value of $0.94 \mathrm{~N}$. The decreasing trend in springiness may be due to diminishing muscle fibrils aggregation's strength over the storage time. In chewiness value, a decreasing trend was noticed during the storage period, which decreased to $4.45 \mathrm{~N}$ from an average initial value of $7.31 \mathrm{~N}$. The chewiness value could decrease while decreasing the hardness value directly proportional to hardness (chewiness $=$ hardness $\times$ cohesiveness $\times$ springiness) .

\subsection{Color change}

Changes in color characteristics of basa fish fillets during storage in STC at $5 \pm 0.2^{\circ} \mathrm{C}$ are presented in table 2 . The results showed that the $\mathrm{L}^{*}$ (lightness) and $\mathrm{a}^{*}$ (redness) values decreased significantly, whereas $b^{*}$ (yellowness) and color change $(\Delta E)$ values increased over the storage period. The $\mathrm{L}^{*}$ value dropped from an initial value of 63.74 to 57.83 . The a ${ }^{*}$ value also decreased from an initial value of 4.86 to 3.07 . The $b^{*}$ value was observed to be 15.27 on the initial day however increased to 18.76 on the $10^{\text {th }}$ day. On day 10 , the $\Delta \mathrm{E}$ value was 7.06 .

\subsection{Microbial load}

In the present study, the psychrotrophic bacteria counts in pangasius fish fillets were determined by plate count agar (PCA) test, and results are reported in Table 2. The work shows that the total psychrotrophic count increased significantly over the storage period. The total psychrotrophic count in the pangasius fillets was $2.13 \log \mathrm{CFU} / \mathrm{g}$ at the beginning of a trial, which indicates the initial quality of fish fillets used in this study was good. On the other hand, it increased to $4.26 \log \mathrm{CFU} / \mathrm{g}$ on the $10^{\text {th }}$ day. The total psychrotrophic count in the study was in good agreement with the general limit of $7 \log \mathrm{CFU} / \mathrm{g}$ for raw fish products (Mohan et al., 2008).

\subsection{Sensory characteristics}

The sensory scores of cooked Pangasius fillets during storage is presented in Table 2. It is clear from the table that the sensory values decreased significantly over the storage period. The sensory scores for flavor, juiciness, texture, taste, and overall acceptability were recorded between 6.0 and 7.0 on the $6^{\text {th }}$ day. On the other hand, their values were in the range of 5.2-6.0 on the $10^{\text {th }}$ day. However, the sensory scores on juiciness were slightly less than other scores on other parameters during storage. The present study samples were acceptable for up to 10 days since the sensory score of 4.0 is an account of a lower limit of the overall acceptability.

\section{Discussion}

The degree of lipid oxidation can be assessed by the TBA index, which measures malonaldehyde (MDA) content (Mohan et al., 2008). The MDA is a principal component formed during the oxidation of polyunsaturated fatty acids. The higher TBA value indicates fat degradation compounds such as free fatty acids and peroxide. Lipid oxidation, corresponding to the oxidative deterioration of polyunsaturated fatty acids in fish muscle, leads to off-flavor production, thereby shortening the shelf life of fish (Secci \& Parisi, 2016). The results were confirmed with the findings of Viji et al. (2015), who demonstrated the TBA value of $1.0 \mathrm{mg} \mathrm{MDA} / \mathrm{kg}$ sample for gutted sutchi catfish on the $20^{\text {th }}$ day at $1-2^{\circ} \mathrm{C}$. Hassan et al. (2016) reported that the TBA value of $P$. hypophthalmus mince was $1.33 \mathrm{mg} \mathrm{MDA} / \mathrm{kg}$ sample on the 6th day at $3-5^{\circ} \mathrm{C}$. On the other hand, Sriket \& La-ongnual (2018) showed the TBA value of 2.0 and $4.0 \mathrm{mg} \mathrm{MDA} / \mathrm{kg}$ sample on $2^{\text {nd }}$ and $4^{\text {th }}$ week, respectively for basa fish fillets at $-20^{\circ} \mathrm{C}$. This fluctuation in TBA may be due to temperature; the rate of lipid oxidation is directly associated with the weather (Mohan et al., 2008).

Peroxide is a measure of the concentration of hydroperoxides, products of lipid oxidation, which leads to degradation of fish meat quality during storage. The literature showed that meat and oil's peroxide value to maintain their quality without rancidity flavor is in the range of $10-20 \mathrm{mEqO}_{2} / \mathrm{kg}$ fat (Kong \& Singh, 2011). The increase in peroxide value could be attributed to the oxidation of unsaturated fatty acids, thus increasing free oxygen availability. A similar increasing trend in peroxide value was reported by Mohan et al. (2008) for catfish steaks during chilled storage $\left(0-2^{\circ} \mathrm{C}\right)$ for 10 days, Ehsani \& Jasour (2012) for rainbow trout fillets during refrigerated storage $\left(4^{\circ} \mathrm{C}\right)$ for 12 days, and Viji et al. (2015) for gutted sutchi catfish during ice storage at $1-2^{\circ} \mathrm{C}$.

$\mathrm{pH}$ is an indicator of the spoilage pattern of fish during storage. Storage time tends to increase the $\mathrm{pH}$ value, which can be associated with the production of ammonia, volatile alkali, and trimethylamine due to internal enzymatic activity (Chamanara et 
al., 2012) and due to lactic acid build-up because of the disintegration of glycogen during the post-mortem process (Remya et al., 2018). $\mathrm{pH}$ also influences the degradation of myofibrillar proteins, which stimulates the gel-forming ability of minced fish. The myofibrillar proteins are unstable and rapidly lose ATPase activity with excessive $\mathrm{pH}$ changes (Hassan et al., 2016).

The Water binding ability refers to the bound moisture available in the muscle. It is an indicator of the water holding capacity of minces that has a direct correlation between myofibrillar protein content and gel strength of the product (Smith, 1987). The present results were confirmed with the findings of Binsi et al. (2015) and Hassan et al. (2016), who reported an increasing trend in drip loss of vacuum-packed freshwater catfish during chill storage at $4 \pm 2{ }^{\circ} \mathrm{C}$ and $P$. hypophthalmus mince during storage in the refrigerator (3$\left.5^{\circ} \mathrm{C}\right)$, respectively.

Food texture is referred to as the degree of hardness or softness, measured in terms of force (kgf) required to deform or penetrate or cut out the food material. The compressive force depends on the hardness or softness of the food tissues and is directly proportional to the hardness (Kandasamy \& Mukherjee, 2019). The texture profile describes the muscle tissue properties such as hardness, cohesiveness, springiness, gumminess, and chewiness (Sun et al., 2018). The connective tissues in fish muscle ruptured and turned softer due to degradation of the myofibrillar protein (Viji et al., 2015). The protein degradation may be attributed to the activity of the endogenous enzymes and the reaction between protein and water molecules (Sun et al., 2018). Similarly, Liu et al. (2013) observed that the hardness of grass carp fillets decreased sharply within the first 3 days, both at $-3^{\circ} \mathrm{C}$ and $0^{\circ} \mathrm{C}$. In this study no significant change in cohesiveness throughout the storage period.

Cohesiveness and springiness are texture properties used for describing the elastic behavior, i.e., the ability of muscles to deform when compressed and return their original form after compression is removed and their resistance to consequent deformation (Hassoun \& Karoui, 2016). A cohesiveness value of 0.0 indicates plasticity characteristics, and a value of 1.0 indicates total elasticity (Viji et al., 2015; Manju et al., 2007). The present results were in good agreement with findings of the published literature, showed no significant change in the cohesiveness of whiting fillets at $4^{\circ} \mathrm{C}$ during 15 days (Hassoun \& Karoui, 2016) and mandarin fish (Siniperca chuatsi) fillets at $4^{\circ} \mathrm{C}$ over 4 days (Sun et al., 2018).

Springiness deals with the elastic behavior of the fish muscle. The degree of softness of fish fillets over the storage period could be the reason for decreasing in the chewiness value. A similar decreasing trend in springiness and chewiness values were reported by Manju et al. (2007) for Pearl spot fish under air and vacuum during 17 days storage at $0-2^{\circ} \mathrm{C}$, Gao et al. (2014) for pompano fillets at $4 \pm 1^{\circ} \mathrm{C}$ over 15 days, Viji et al. (2015) for sutchi catfish at $1-2^{\circ} \mathrm{C}$ over 22 days, Hassoun \& Karoui (2016) for whiting fillets during 15 days storage at $4^{\circ} \mathrm{C}$ and Sun et al. (2018) for mandarin fish during 5 days storage at $4^{\circ} \mathrm{C}$.

The color is an important physical property that describes the freshness of fish meat products and enhances consumer acceptability and market value (Gao et al., 2014); thus, color stability during storage is an essential factor in fish preservation. The color of fish muscle is mainly influenced by the concentration of pigment and muscle structure characteristics (Gao et al., 2014), and they reported that a decreasing trend in lightness $\left(\mathrm{L}^{*}\right)$ and whiteness values whereas an increasing trend in blueness $\left(b^{*}\right)$ value for pompano fish fillets during storage at $4 \pm 1^{\circ} \mathrm{C}$ for 15 days. Lipid oxidation, pigment degradation, reactions between aldehydes, ketones, and amino acids over the storage time lead to discoloration of the fish muscle (Sriket \& La-ongnual, 2018). Reduction in redness due to heme oxidation leads to browning of the bloodline, increasing yellowness (Kulawik et al., 2016). We also confirmed our results with the findings of Sriket \& Laongnual (2018). They showed a significant reduction in $L^{*}$ and $a^{*}$ values and an increase in $\mathrm{b}^{*}$ value for basa $(P$. bocourti) fillet during frozen storage at $-20^{\circ} \mathrm{C}$ for 20 weeks. Greeshma et al. (2019) also reported a similar decreasing trend in $\mathrm{L}^{*}, \mathrm{a}^{*}$, and $\mathrm{b}^{*}$ values for vacuum packaged $P$. hypophthalmus fillets during chilled storage at $2 \pm 1^{\circ} \mathrm{C}$ for 18 days.

The physiological condition, temperature, and microbial contamination are the primary sources for the deterioration of fish during storage. Low temperature is the most decisive impact in controlling the growth of endogenous enzymes and bacteria. The development of psychrotrophic microorganisms is effective retards below $5^{\circ} \mathrm{C}$ (Erkmen \& Bozoglu, 2016). An increasing trend in psychrotrophic counts was reported by Remya et al. (2018) for barracuda Sphyraena jello steaks during chilled storage at $0-2^{\circ} \mathrm{C}$.

Sensory characteristics play a significant role in describing the overall acceptability of fish products for human consumption. The lowest limit of the acceptable sensory score for human consumption is 4.0 (Manju et al., 2007). The sensory attributes indicate the solar thermoelectric cooler has a great potential in increasing the shelf life of basa fish fillets up to 10 days. Our results were in good agreement with the findings of Manju et al. (2007), who reported the sensory scores of pearl spot fish packed in different packs were declined to 3.4-3.8 on the 10th day from an initial value of 8.6 at $0-2^{\circ} \mathrm{C}$. Mohan et al. (2008) reported similar findings for air-packed catfish steaks and Binsi et al. (2015) for vacuum-packed catfish.

\section{Conclusion}

In this work, STC was fabricated and evaluated its coefficient of performance. The STC's cooling impact on quality parameters of 
the basa fish fillets includes TBA, peroxide, $\mathrm{pH}$, WBA, TPC, texture profile, color, and sensory attributes, were evaluated. The result indicates that the STC temperature decreased to $7.4^{\circ} \mathrm{C}$ from $30^{\circ} \mathrm{C}$ within $90 \mathrm{~min}$, and then gradually reduced, reached to $5 \pm 0.2^{\circ} \mathrm{C}$ in $150 \mathrm{~min}$. The maximum voltage of $12 \mathrm{~V}$ was observed when the input electric current of $3.5 \mathrm{~A}$. Therefore, it was assumed as a design point to estimate the cooling capacity and COP of the STC. The cooling capacity and COP were found to be $23.8 \mathrm{~W}$ and 0.44 , respectively. The quality parameters, TBA, peroxide, $\mathrm{pH}$, WBA, and TPC, were increased significantly during the storage period of 10 days. The texture profile properties, hardness, springiness, and chewiness values decreased, whereas no significant change in cohesiveness. The color $\mathrm{L}^{*}$ and $\mathrm{a}^{*}$ values were increased significantly, whereas $b^{*}$ and decreased color change $(\Delta \mathrm{E})$ values. However, such changes were within the acceptable level concerning the published works. The sensory scores were found in the range of 5.2-6.0 on the $10^{\text {th }}$ day. Since the sensory score of 4.0 is an account of the lower limit of the overall acceptability, the stored fish fillets are acceptable for 10 days. It can conclude that the STC could be an alternate green option for the preservation of fish and other perishable products where inconsistent electricity supply.

\section{Acknowledgments}

The authors acknowledge financial support from the Department of Science and Technology, Government of India (Ref No: DST/INSPIRE Fellowship/IF170433 dated: 10 January 2018). The authors wish to thank the Department of Agricultural Engineering, Visva-Bharati University, West Bengal, Faculty of Fishery Science, West Bengal University of Animal \& Fishery Sciences, India, for providing laboratory facilities and immense technical supports.

\section{Conflict of interest}

The authors declare that they have no conflict of interest.

\section{Nomenclature}

$\mathrm{Q}_{\mathrm{w}}$ - amount of heat transfer through walls of cooler box $(\mathrm{W}) ; \mathrm{A}_{\mathrm{c}}$ area of the cooler walls $\left(\mathrm{m}^{2}\right)$; $\mathrm{U}$ - overall heat transfer coefficient $\left(\mathrm{W} / \mathrm{m}^{2} \mathrm{~K}\right) ; \mathrm{T}_{0}$ - average outside air temperature $\left({ }^{\circ} \mathrm{C}\right) ; \mathrm{T}_{\mathrm{i}}$ - inside temperature of the cooling chamber $\left({ }^{\circ} \mathrm{C}\right) ; \mathrm{K}_{\mathrm{p}}$ - thermal conductivity of HDPE wall $(\mathrm{W} / \mathrm{mK}) ; \mathrm{K}_{\mathrm{i}}$ - thermal conductivity polyurethane insulation foam $(\mathrm{W} / \mathrm{mK}) ; \mathrm{X}_{\mathrm{p}}$ - thickness of HDPE wall (m); $\mathrm{X}_{\mathrm{i}}$ thickness of insulating material $(\mathrm{m}) ; \mathrm{Q}_{\mathrm{m}}$ - conduction heat loss inside the TEM (W); $\mathrm{K}_{\mathrm{m}}$ - thermal conductivity of Bismuth telluride, $\mathrm{Bi}_{2} \mathrm{Te}_{3}(\mathrm{~W} / \mathrm{mK}) ; \mathrm{A}_{\mathrm{m}}$ - cross-sectional area of the TEM $\left(\mathrm{m}^{2}\right) ; \mathrm{X}_{\mathrm{m}}$ - thickness of length of the TEM $(\mathrm{m}) ; \mathrm{Q}_{\mathrm{p}}$ - heat energy of the product $(\mathrm{W}) ; \mathrm{M}_{\mathrm{p}}$ - mass of the fish fillets $(\mathrm{kg}) ; \mathrm{C}_{\mathrm{p}}$ - specific heat capacity of the fish product $(\mathrm{kJ} / \mathrm{kg} \mathrm{K}) ; \mathrm{T}_{\mathrm{pi}}$ - initial temperature of the fish product $\left({ }^{\circ} \mathrm{C}\right) ; \mathrm{T}_{\mathrm{pf}}$ - final temperature of fish product $\left({ }^{\circ} \mathrm{C}\right)$; $\mathrm{Q}_{\mathrm{f}}$ - heat energy of the fan $(\mathrm{W}) ; \mathrm{N}_{\mathrm{f}}$ - number of fans; $\mathrm{F}_{\mathrm{r}}$ - rating of fan $(\mathrm{W}) ; \mathrm{Q}_{\mathrm{c}}$ - cooling capacity or amount of heat pumped by the TEM (W); $\alpha$ - Seebeck coefficient of the TEM (V/K); R electrical resistance of the TEM $(\Omega)$; K - thermal conductance of $\mathrm{TEM}\left(\mathrm{W} / \mathrm{m}^{2} \mathrm{~K}\right) ; \mathrm{T}_{\mathrm{c}}$ - temperature at the cold side of the TEM $\left({ }^{\circ} \mathrm{C}\right)$; $\mathrm{T}_{\mathrm{h}}$ - temperature at the hot side of the TEM $\left({ }^{\circ} \mathrm{C}\right) ; \Delta \mathrm{T}$ - temperature difference between hot and cold side of the TEM $\left({ }^{\circ} \mathrm{C}\right)$; I - electrical current $(\mathrm{A}) ; \mathrm{V}$ - voltage $(\mathrm{V}) ; \mathrm{P}_{\mathrm{f}}$ - power consumption of the fans (W)

\section{References}

Abdul-Wahab SA, Elkamel A, Al-Damkhi AM, Al-Habsi IA, AlRubai'ey HS, Al-Battashi AK, Al-Tamimi AR, Al-Mamari KH, Chutani MU (2009) Design and experimental investigation of portable solar thermoelectric refrigerator. Renewable Energy 34: 30-34. https://doi.org/10.1016/j.renene.2008.04.026.

Aboelmaaref MM, Zayed ME, Elsheikh AH, Askalany AA, Zhao J, Li W, Harby K, Sadek S, Ahmed MS (2020) Design and performance analysis of a thermoelectric airconditioning system driven by solar photovoltaic panels. Proceedings of the Institution of Mechanical Engineers, Part C: Journal of Mechanical Engineering Science 234(24): 1-14. https://doi.org/10.1177/ 0954406220976164.

American Oil Chemists' Society (AOCS) (1992) Peroxide value acetic acid-chloroform method. In: Firestone D (Ed.), Official Methods and Recommended Practices, American Oil Chemists' Society, Champaign, Illinois, United States.

American Public Health Association (APHA) (1992) Compendium of methods for the microbiological examination of foods. $\left(2^{\text {nd }}\right.$ Edn.). Washington D.C: American Public Health Association.

Binsi PK, Viji P, Visnuvinayagam S, Ninan G, Sangeeta G, Triveni A, Ravishankar CN, (2015) Microbiological and shelf-life characteristics of eviscerated and vacuum-packed freshwater catfish (Ompok pabda) during chill storage. Journal of Food Science and Technology 52(3): 1424-1433. https://doi.org/10.1007/s13197-013-1165-x.

Bjørk R, Christensen DV, Eriksen D, Pryds N (2014) Analysis of the internal heat losses in a thermoelectric generator. International Journal of Thermal Sciences 85: 12-20. http://dx.doi.org/10.1016/ j.ijthermalsci.2014.06.003.

Chamanara V, Shabanpour B, Gorgin S, Khomeiri M (2012) An investigation on characteristics of rainbow trout coated using chitosan assisted with thyme essential oil. International Journal of Biological Macromolecules 50(3): 540-544. https://doi.org/ 10.1016/j.ijbiomac.2012.01.016. 
Chen Y, Chien Z, Lee W, Jwo C, Cho K (2014) Experimental investigation on thermoelectric chiller driven by the solar cell International Journal of Photoenergy Article ID 102510. https://doi.org/10.1155/2014/102510.

Dai YJ, Wang RZ, Ni L (2003) Experimental investigation and analysis on a thermoelectric refrigerator driven by solar cells. Solar Energy Materials and Solar Cell 77(4): 377-391. https://doi.org/10.1016/S0927-0248(02)00357-4

Ehsani A, Jasour MS (2012) Improvement of lipid stability of refrigerated rainbow trout (Oncorhynchus mykiss) fillets by prestorage $\alpha$-tocopherol acetate dipping treatment. Veterinary Research Forum 3(4): 269-273.

Erkmen O, Bozoglu TF (2016) Food Microbiology: Principles and Practice ( $1^{\text {st }}$ ed) John Wiley \& Sons, New Jersey, USA.

Gao M, Feng L, Jiang T, Zhu J, Fu L, Yuan D, Li J (2014) The use of rosemary extract in combination with nisin to extend the shelf life of pompano (Trachinotus ovatus) fillet during chilled storage. Food Control 37: 1-8. https://doi.org/10.1016/j.foodcont.2013.09.010.

Gökçek M, Şahin F (2017) Experimental performance investigation of mini channel water cooled-thermoelectric refrigerator. Case Studied in Thermal Engineering 10: 54-62. https://doi.org/10.1016/j.csite.2017.03.004

Greeshma SS, Sarika K, Priya ER, Lekshmi RG, Kumar Joseph TC, Pandey MC, Prasad MM (2019) Shelf life characteristics of Pangasianodon hypophthalmus fillets treated with Moringa oleifera (Lam) Leaf extract. Fishery Technology 56: 285-291.

Guimarães CFM, Mársico ET, Monteiro MLG, Lemos M, Mane SB, Junior CAC (2016) The chemical quality of frozen Vietnamese Pangasius hypophthalmus fillets. Food Science \& Nutrition 4(3): 398-408. https://doi.org/10.1002/fsn3.302.

Guo D, Sheng Q, Dou X, Wang Z, Xie L, Yang B (2020) Application of thermoelectric cooler in temperature control system of space science experiment. Applied Thermal Engineering 168 114888. https://doi.org/10.1016/j.applthermaleng.2019.114888.

Hassan A, Chongtham BS, Xavier KAM, Amjad B (2016) Effect of cryoprotectants on the quality of Pangasius hypophthalmus mince during refrigerated storage. Journal of Environment and Bio-science 30: 283-288.

Hassoun A, Karoui R (2016) Monitoring changes in whiting (Merlangius merlangus) fillets stored under modified atmosphere packaging by front face fluorescence spectroscopy and instrumental techniques. Food Chemistry 200: 343-353. https://doi.org/10.1016/j.foodchem.2016.01.028.
Kandasamy P, Mukherjee S (2019) Enhancing shelf life of tomato under controlled atmosphere condition using a diffusion channel system. Engineering in Agriculture, Environment and Food 12(1): 1-10. https://doi.org/10.1016/j.eaef.2018.07.001

Khalili Tilami S, Sampels S (2018) Nutritional Value of Fish: Lipids, Proteins, Vitamins, and Minerals. Reviews in Fisheries Science and Aquaculture 26(2): 243-253. https://doi.org/10.1080/23308249.2017.1399104.

Kong F, Singh RP (2011) Advances in instrumental methods to determine food quality deterioration. In: Kilcast D, Subramaniam P (Ed.), Food and Beverage Stability and Shelf Life. United Kingdom: Woodhead Publishing Limited, 381-404. https://doi.org/10.1533/9780857092540.2.381.

Kulawik P, Migdal W, Tkaczewska J, Özoğul F (2016) Assessment of colour and sensory evaluation of frozen fillets from pangasius catfish and Nile tilapia imported to European Countries. International Journal of Food Properties 19(7): 1439-1446. https://doi.org/10.1080/10942912.2015.1079790.

Leary S, Underwood W, Anthony R, Corey D, Grandin T, Gwaltney-Bran S, Meyer R Regenstein J, Shearer J, Smith SA (2016) AVMA guidelines for the humane slaughter of animals: 2016 edition. Schaumburg, IL: American Veterinary Medical Association, Pp. 50-52.

Liu D, Liang L, Xia W, Regenstein JM, Zhou P (2013) Biochemical and physical changes of grass carp (Ctenopharyngodon idella) fillets stored at -3 and $0^{\circ} \mathrm{C}$. Food Chemistry 140: 105-114. https://doi.org/10.1016/j.foodchem.2013.02.034.

Manju S, Jose L, Gopal TKS, Ravisankar CN, Lalitha KV (2007) Effect of sodium acetate dip treatment and vacuum-packaging on chemical, microbiological, textural and sensory changes of pearl spot (Etroplus suratensis) during chilled storage. Food Chemistry 102: 27-35. https://doi.org/10.1016/j.foodchem.2006.04.037.

Mirmanto M, Syahrul S, Wirdam Y (2019) Experimental performances of a thermoelectric cooler box with thermoelectric position variations. Engineering Science and Technology, an International Journal 22: 177-184. https://doi.org/10.1016/ j.jestch.2018.09.006.

Mohan CO, Ravishankar CN, Srinivasagopal TK (2008) Effect of $\mathrm{O} 2$ scavenger on the shelf-life of catfish (Pangasius sutchi) steaks during chilled storage. Journal of the Science of Food and Agriculture 88(3): 442-448. https://doi.org/10.1002/jsfa.3105.

Nielsen J, Jessen F (2007) Quality of Frozen Fish. In L. M. L. Nollet (Eds.), Handbook of Meat, Poultry and Seafood Quality. Iowa: Blackwell Publishing. Pp 577-586. 
Ohara B, Sitar R, Soares J, Novisoff P, Nunez-Perez A, Lee A (2015) Optimization strategies for a portable thermoelectric vaccine refrigeration system in developing communities. Journal of Electronic Materials 44: 1614-1626. https://doi.org/10.1007/ s11664-014-3491-9.

Remya S, Mohan CO, Ravishankar CN, Sivaraman GK, Jha AK, Venkateshwarlu G (2018) Effect of active packaging atmosphere on the shelf life of chilled stored steaks of barracuda Sphyraena jello. Indian Journal of Fisheries 65(4): 109-115. https://doi.org/10.21077/ijf.2018.65.4.78257-13.

Secci G, Parisi G (2016) From farm to fork: Lipid oxidation in fish products. A review. Italian Journal of Animal Science 15(1): 124 136. https://doi.org/10.1080/1828051X.2015.1128687.

Smith DM (1987) Functional and biochemical changes in deboned Turkey due to frozen storage and lipid oxidation, Journal of Food Science 52(1): 22-27. https://doi.org/10.1111/j.13652621.1987.tb13965.x.
Sriket P, La-ongnual T (2018) Quality changes and discolouration of basa (Pangasius bocourti) fillet during frozen storage. Journal of Chemistry 2018: 5159080. https://doi.org/10.1155/2018/ 5159080

Sun Y, Ma L, Ma M, Zheng H, Zhang X, Cai L, Li J, Zhang Y (2018) Texture characteristics of chilled prepared Mandarin fish (Siniperca chuatsi) during storage. International Journal of Food Properties 21(1): 242-254. https://doi.org/10.1080/10942912.2018.1451343.

Tarladgis BG, Watts BM, Younathan MT, Dugan LR (1960) A distillation method for the quantitative determination of malonaldehyde in rancid foods. Journal of American Oil Chemists' Society 37: 44-48. https://doi.org/10.1007/BF02630824.

Viji P, Tanuja S, Ninan G, Lalitha KV, Zynudheen AA, Binsi PK, Srinivasagopal TK (2015) Biochemical, textural, microbiological and sensory attributes of gutted and ungutted sutchi catfish (Pangasianodon hypophthalmus) stored in ice. Journal of Food Science and Technology 52(6): 3312-3321. https://doi.org/10.1007/s13197-014-1358-y. 